\title{
Traditional Versus Modern Procedures of Village Head Election in Indonesia
}

\author{
Andi Alimuddin ${ }^{1}$, Andi Gau Kadir ${ }^{2}$, Rahmatia Yunus ${ }^{3}$, Dwia Aries Tina Pulubuhu ${ }^{4}$, Seniwati ${ }^{5 a}$ \\ ${ }^{1}$ Department of Communication, Hasanuddin University, Makassar, Indonesia \\ ${ }^{2}$ Department of Politics and Government, Hasanuddin University, Makassar, Indonesia \\ ${ }^{3}$ Department of Economic, Hasanuddin University, Makassar, Indonesia \\ ${ }^{4}$ Department of Sociology Department, Hasanuddin University, Makassar, Indonesia \\ ${ }^{5}$ Department of International Relations, Hasanuddin University, Makassar, Indonesia \\ ${ }^{a}$ Corresponding author: seniwati_2006@yahoo.co.id
}

\begin{abstract}
This research focuses on the traditional versus modern methods in conducting the election of the head of a village in Indonesia. A village head has a major role in organizing and managing community interests. In participating in the election of the village head, a village head must deliver his the programs. One tool that can be utilized in delivering some programs is social media. Despite so, there are some village heads that use the traditional ways, which are commonly known as 'door to door' approach. The purpose of this study is to investigate traditional versus modern methods as a technique of village head in transmitting and spreading programs to people. The research design of this study is qualitative study. This research used interviewing method. This research was conducted in Makkawaru Village, Mattiro Bulu Subdistrict, Pinrang Regency, and South Sulawesi Province. This research found that the use of social media and Internet is still infrequent among the villagers. Most of which use social media and the Internet is generally still among the youth. The candidates of village heads in delivering campaign programs are still traditional.
\end{abstract}

Keywords - traditional method, modern method, election of the village head, transmitting, spreading program

\section{INTRODUCTION}

The election of the village head is one of the ways in implementing the democratic system that is adopted by the Indonesian Country. The election of the village head is one manifestation of the practice of direct democracy. In the national system of government, the village government is the lowest structure. Therefore, an elected village head must be able to carry out the mandate of the community from all levels, groups and interests.

The Government Regulation of the Republic of Indonesia Number 72 Year 2005 regarding Villages stated that the Village is a unit of law society which has the boundaries of the territory authorized to organize and manage the interests of the local community based on the origin and local customs that are recognized and respected in the system of the Government of the Unitary State of the Republic Indonesia [1]. The Government of Indonesia Regulation further states that the Village Government is the administration of government affairs by the Village Government and Village Consultative Body in arranging and managing the interests of the local community based on the origin and local customs that are recognized and respected in the system of Government of the Unitary State of the Republic of Indonesia [1]. This sentence shows the critical role of a village head in organizing and managing community interests.

In participating in the election of the village head, a village head must deliver his the programs. One tool that can be used in delivering proposed programs is through the social media. Despite so, there are some village heads that use the traditional ways that are commonly known as 'door to door' approach. Haryani and Motwani explained in his article "Information plus be distributed by online communities, social networks, blogs and forums, and also online videos and emails [3]. Social media can convey messages quickly and can also reach a large number of people. Moreover, the cost is also much cheaper compared to the 'door-to-door' approach. However, the 'doorto-door' approach is still widely used in village head elections that are held in villages in Indonesia. The purpose of this study is to investigate traditional versus modern methods as a technique of village head in transmitting and spreading programs to people.

\section{RELATED WORK}

Vilpponen et.al. in their article about a network of electronic word-of-mouth referral communication in the fact online. The goals of their research were to know the existing terminology of electronic word-of-mouth behavior, to analyze the emergence of the kind of network structure in the electronic environment, and to examine the relation between the acceptance of an innovation and the network structure. Their research found that there are differences between the traditional interpersonal communication network structure and the structure of an electronic communication network. Their research also indicated that innovation adoption timing is affected by the network structure in the electronic communication [10].

Haryani and Motwani in their research said that the internet and online business have become very popular recently therefore viral marketing become an important tool in the communication sector. Then, there is some factor that influences the consumer's purchasing such as message 
material, consumer dependency, supportive access, immense efficacy, and professed security [3].

\section{RESEARCH METHODOLOGY}

The research design of this study is qualitative study. Qualitative approach recognizes case study, ethnography, phenomenology, and among others. This research adopted case study type. Starman recognizes that one of type of qualitative research is a case study [10]. Sagadin states that we can use case study to analyze and describe activities, special needs, life situation, life history of person individually; a group people such as a group of students with special needs, a school department, teaching staff, etc.; a problem or several problems of individual institutions, phenomenon, process, or institutions, etc. [10]. Qualitative research could explore a wide array of social world dimensions such as the understanding, the texture and weave of everyday life, the ways of social processes, institutions, imaginings and experiences of participants of research, and relationships work or discourses [4]. This research used interviewing method. Mason in her book stated that 'the term 'qualitative interviewing' is usually intended to refer to in-depth, loosely structured forms of interviewing or semi-structured, the term 'unstructured' interviewing” [4]. This research adopted the term 'unstructured' interviewing. We used this method because the data obtained were more complete and also depends on the individuals interviewed. This research was conducted in Makkawaru Village, Mattiro Bulu Subdistrict, Pinrang Regency, South Sulawesi Province. The study was conducted from April to July 2017. Interviews were held with Village Heads, Community Leaders, Customary Leaders, Religious Leaders, and Local Government Officials. The data was also obtained from several stakeholders in the form of Focus Group Discussion. There are eight sources of informant from the younger generation who are considered to have skills in using social media and the Internet.

\section{ANALYSIS}

There are several indicators to conduct the interview. First, there is a value such as financial rewards [7]. Prospective village heads can use social media in delivering their vision and mission so that the costs incurred can be cheaper. Second, there is a positive linkage with youth attitude towards SMS advertising [5]. This means that the role of SMS is important in influencing voters because SMS message are easily understood and provide the relevant information. Third, Haghirian in her article said that the content and the frequency of the advertising message have an important role in sending a the role important to send message via mobile devices [2]. SMS or Short Message Service has the important role in an campaign. Therefore, a good message of SMS consists of a clear and short sentence.

\section{DISCUSSION}

Samad as Makkawaru Village Chief said that in conveying a message when conducting a village head election campaign in 2015 most of the methods used are still traditional. Other candidates for village heads are still using the same approach. They compete in seeking community support through the traditional system [8]. The traditional way in campaigning the programs is by visiting the religious and community leaders in their homes. This way aims to get more support through these religious and community leaders. They will spread their influence to the people. Candidates for village head believe that the religious and the community leaders can use their influence because people still want to hear their words. This is expressed by Ustadz Sanuzi as one of the religious figures residing in the village. Ustadz Sanuzi said that the candidate head of the village came to him to ask for advice and support on the programs that are made by the village head [9].

Nevertheless, Samad does not deny the benefits that are gained when using social media in financial terms. Some successful teams from the candidate of village heads used SMS in campaigns or deliver programs of candidates of village heads to their friends and colleges. The content of messages from SMS is made short and definite, so that makes people easy to understand. This SMS is targeted at youths of village organizations. This successful team promises facilities that can support the development of youths of village organizations. This method is easy to be accepted by youth organizations because they receive considerable attention from their village head candidates.

Submission of information via SMS is one manifestation of Viral Marketing Campaign. Haryani and Motwani in their article said that viral marketing uses the Internet as a technique for spreading and transmitting message among individuals who will send message contents to their friends [3]. The message via the Internet as the one of indicator above can make the cost cheaper and the community can more quickly and easily accept delivered messages.

Samad an elected village chief said that in the 2015 campaign, the Internet was still rarely used. This is due to the people who have mobile phones that can use the Internet is still rare. Nevertheless, there are some successful Samad team members that use the Internet in delivering messages such as Facebook, E-mail, Blog, Line and What Sapp. Some Facebook, E-mail, Blog, Line and What Sapp users are young people who are aged between 17 to 30 years.

Samad's successful team can share information through Facebook, E-mail, Blog, Line and What Sapp to the community about village development programs and programs that have not been successful in the previous period. The number of people who use Internet facilities in the village is very little. Therefore most of the political campaigns used by prospective village heads in 2015 are still traditional approaches.

This research held a workshop on the importance of social media and Internet role in supporting the programs of a village head candidate. This workshop explains the importance of online viral marketing in attracting positive perceptions of the public. Online viral marketing can promote the programs of a candidate village head effectively and does not require a high cost. The impact of the promotion has a significant effect on the prospective voters in favor of a candidate of the village head who is considered to have good programs.

This workshop explains that social media can serve as a control tool. Social media can be a tool of control over government and election organizers because it is transparent, 
legal and credible. Social media can help deliver messages quickly and cheaper. Social media can also serve as a tool for conveying community aspirants. Communities can convey their aspirations via SMS messages so that their aspirations are heard and included as one of the programs by the candidate to the village at the time of an election. Then, the elected village head must try to implement the aspirations of this community.

By using the media, candidates of the village head are aware that they must have programs that are acceptable to their citizens so campaigning through social media and the internet is not a physical war but a war of perception. This certainly requires a good strategy so that the community would choose the candidate for the village head.

Social media can also shape public opinion perceptions. Mills said that Viral Marketing has an essential role in building relations between consumers (clients, donors, and volunteer) and organizations [6]. This sentence explains between social media and society as consumers have a positive correlation. Therefore, the workshop encourages that in the future village head elections, a candidate to the village can use social media and the Internet in his campaign.

\section{CONCLUSION}

The use of social media and Internet is still very rare among the villagers. Most of which use social media and the Internet is generally still among the youth. The candidates of village heads in delivering campaign programs are still traditional. It is necessary to attain necessary attention from the government to socialize the benefits of social media and Internet. People need to know that social media makes campaign costs cheaper and efficient.

\section{VI.LIMITATIONS AND FURTHER RESEARCH}

This study does not make differences between male and female informants in using social media and the Internet. Sometimes, female has stronger influence than male. Female can influence her husband or family to choose someone to become head of a village. Therefore, for the next research, cultural influences on gender may be can be developed as an important tool for social media environment.

\section{ACKNOWLEDGMENT}

The researcher wants to thank Ministry of Research, Technology and Higher Education of Republic of Indonesia for his funding to conduct this research under program "Unggulan Perguruan Tinggi (Special Program University). Lastly, the researcher is grateful for citizen, Village Head, Community Leaders, Indigenous Leaders, Religious Leaders of Makkawaru Village, Mattiro Bulu SubDistrict, and Pinrang Regency, South Sulawesi Province for their time to support our data.

\section{REFERENCES}

[1] Government Regulation of the Republic of Indonesia Number 72 Year 2005 regarding Villages.

[2] P. Haghirian, Increasing Advertising Value of Mobile Marketing- An Empiral Study of Antecedents. Proceedings of the $38^{\text {th }}$ Hawaii International Conference on System Sciences. 2005.

[3] S. Haryani, and B. Motwani. "Disriminant Model for online Viral Marketing Influencing Consumers Behavioural Intention.” Pacific Science Review B: Humanities and Social Sciences. 2015. 49-56.

[4] J. Mason, Qualitative Researching: $2^{\text {nd }}$ edition. London: SAGE Publications. 2002.

[5] F. Muzaffar, S. Kamran. "SMS Advertising: Youth Attitude Towards Perceived Informativeness, Irritation and Credibility." Interdisciplinary Journal of Contemporary Research in Business. May. Vol.3 Issue 1. 2011. pp.230-245.

[6] H.D. Parker, H. Diane, K. Wachter, H. Sloan, and V. Ghomi. "Viral Marketing in The Nonprofit Sector: Crafting Messages That Create Awareness and Call an Audience to Action." The Marketing Management Journal. Volume 26, Issue 2, 2016.Pages 101-116.

[7] F. Saadeghvaziri, and H.K. Hosseini. "Mobile Advertising: An Investigation of Factors Creating Positive Attitude in Iranian Customers.” African Journal of Business Management. Vol.5 (2). 2011. pp.394-404, 18 January.

[8] T. Samad, Interviewed. Indonesia: Pinrang Regency. June-July. 2017.

[9] Sanusi, Interviewed. Indonesia: Pinrang Regency. June-July. 2017.

[10] A.B. Starman, "The Case Study as a Type of Qualitative Research." Journal of Contemporary Educational Studies. 2013. Pp.28-43.

[11] A. Vilpponen, S. Winter and S. Sundqvist. "Electronic Word-of-Mouth in Online Environments." Journal of Interactive Advertising. 2014. pp.63-77. 